Article

\title{
The Microstructure and Mechanical Properties of Refractory High-Entropy Alloys with High Plasticity
}

\author{
Yiwen Chen ${ }^{1,2}$, Yunkai Li ${ }^{1,2}$ *, Xingwang Cheng ${ }^{1,2}$, Chao Wu ${ }^{1,2}$, Bo Cheng ${ }^{1,2}$ and Ziqi Xu ${ }^{1,2}$ \\ 1 School of Materials Science and Engineering, Beijing Institute of Technology, Beijing 100081, China; \\ yiwenchen_bit@sina.com (Y.C.); chengxw@bit.edu.cn (X.C.); wuchao19880724@hotmail.com (C.W.); \\ hg2937772@163.com (B.C.); tapiki@126.com (Z.X.) \\ 2 National Key Laboratory of Science and Technology on Materials under Shock and Impact, \\ Beijing 100081, China \\ * Correspondence: 2120161113@bit.edu.cn
}

Received: 15 November 2017; Accepted: 24 January 2018; Published: 29 January 2018

\begin{abstract}
Refractory high-entropy alloys (RHEAs) are promising materials used at high temperature, but their low plasticity restricts their application. Based on the valence electron concentration (VEC) principle, four kinds of RHEAs $\left(\mathrm{ZrTiHfV}_{0.5} \mathrm{Nb}_{0.5}, \mathrm{Zr}_{2.0} \mathrm{TiHfVNb}_{2.0}, \mathrm{ZrTiHfNb}_{0.5} \mathrm{Mo}_{0.5}\right.$, and $\mathrm{ZrTiHfNb}_{0.5} \mathrm{Ta}_{0.5}$ ) are designed (VEC $\left.<4.5\right)$. The experimental results show that the plasticity of these alloys was greatly improved: the static compressive strain was higher than $50 \%$ at room temperature (RT), and some elongations were produced in the tensile process. Moreover, the microstructure and phase composition are discussed in detail. The addition of $\mathrm{Nb}, \mathrm{Mo}$, and Ta contributed to the high-temperature strength. Finally, the dynamic mechanical properties of these RHEAs with coordination between strength and plasticity are investigated.
\end{abstract}

Keywords: RHEAs; alloys design; microstructure and mechanical properties

\section{Introduction}

In recent years, a great number of new ideas have emerged in alloys [1]. High-entropy alloys (HEAs) were proposed by Yeh et al. [2,3], and have attracted much attention because of their extraordinary properties. HEAs are composed of five or more elements with equal or near-equal mole ratios (5-35 at \%). In contrast with traditional theories, HEAs form a simple crystal structure for their high entropy. These alloys have good corrosion resistance [4,5], high hardness [6], and excellent thermal stability [7]. Besides, refractory high-entropy alloys (RHEAs) display good mechanical properties at a high temperature [8-10], as they contain refractory elements ( $\mathrm{Zr}, \mathrm{Ti}, \mathrm{Hf}, \mathrm{V}, \mathrm{W}, \mathrm{Ta}, \mathrm{Mo}$, et al.). For example, the MoNbTaVW alloy possesses a yield strength of $846 \mathrm{MPa}$, even at $800{ }^{\circ} \mathrm{C}$ [8]. However, it is difficult to machine most RHEAs at room temperature (RT), even though some RHEAs have reasonable compression strain [10-12].

The traditional workmanship for improving the deformability of RHEAs is usually adopted, such as changing the grain size and optimizing the distribution of the precipitation phase to modify the external microstructural appearance of alloys $[13,14]$. The intrinsic ductility of RHEAs also requires honing in on the alloy's design process. For stress, dislocation nucleation requires that the local shear stress reaches the ideal values for a perfect crystal. Nevertheless, the initial crack occurs when the local tensile stress perpendicular to the dissociation plane exceeds the ideal tensile strength in metals. This phenomenon causes the activation of dislocation nucleation before the crack formation, which is called shear instability [15]. In this case, the alloys have some inherent plasticity, in that some slip was produced by dislocation. The metals in groups 4 and 5 of the periodic table have a good plasticity due to their shear instability process. For the metals in group 6 , the tensile fracture process finishes before the shear instability process starts, leading to their low plasticity. 
From the perspective of bonding energy, the shear instability process easily occurs when the total energy of alloys is relatively lower. According to the Jahn-Teller deformation $[16,17]$, the bonding energy of alloys decreases through the splitting of the near degenerate orbital, and decreasing the valence electron concentration (VEC) can increase the driving force of the Jahn-Teller deformation. Consequently, alloys with a low VEC are conductive to the occurrence of shear instability. Previous studies have illustrated that RHEAs possess good plasticity when the VEC is lower than 4.5 [17].

In this paper, four kinds of RHEAs are designed according to the above VEC principle. The static compressive strain of these alloys was higher than $50 \%$ and unfaulted at RT. Some elongations were produced in the tensile process, and the tensile strain decreased with increasing VEC. In addition, high-temperature and dynamic mechanical properties are discussed.

\section{Experimental Methods}

The ingots of four kinds of RHEAs were prepared by arc melting under a purified argon atmosphere. The cooling system employed a water-cooled copper crucible. Due to the high melting point of these alloys, relatively large current (350-450 A) and voltage (12-15 V) were used in the melting process. The low-melting metals were placed lower at the bottom and the ingots were remelted at least six times, which guaranteed the homogeneity of the composition. The shape of these ingots was similar to a button, and the height of the thickest part was about $14 \mathrm{~mm}$. The crystal structure was characterized with an $\mathrm{X}$-ray diffractometer with $\mathrm{Cu}-K_{\alpha}$ radiation. The 2-theta scan ranged from 20 degrees to 90 degrees at a speed of $0.2 \mathrm{~s} / \mathrm{step}$. After being polished and etched (the corrosive liquid consisted of $\mathrm{HF}, \mathrm{HNO}_{3}$, and $\mathrm{H}_{2} \mathrm{O}$ ), the specimens were observed in the metallographic microscope. A scanning electron microscope (SEM, HITACHIS4800, Tokyo, Japan,) was used to analyze the microstructure.

The microhardness of RHEAs was measured by a 450SVD ${ }^{\mathrm{TM}}$ Vicker's hardness tester (London, UK) under the load of $300 \mathrm{~g}$ (applied for $15 \mathrm{~s}$ ). The ultimate hardness was averaged by five values, which were tested in different positions. The static compressive properties were tested on the Instron 5569 electronic universal testing machine (Boston, MA, USA) with a strain rate of $10^{-3} \mathrm{~S}^{-1}$. The specimen was the shape of a cylinder $(\phi 4 \mathrm{~mm} \times 6 \mathrm{~mm})$. The tensile properties were tested on a tensile testing machine produced by Instron Company (Boston, MA, USA). The size of the tensile sample adopted was GB/T228-2002. The high-temperature compressive performances were performed on a Gleeble-3500 thermal simulator (Poestenkill, New York, NY, USA) with a Pt-Rh alloys thermocouple. The specimen was the shape of a cylinder $(\phi 6 \mathrm{~mm} \times 9 \mathrm{~mm})$ and the heating rate was set at $300{ }^{\circ} \mathrm{C} / \mathrm{min}$. Each alloy was heated to $700{ }^{\circ} \mathrm{C}, 800{ }^{\circ} \mathrm{C}$, and $900{ }^{\circ} \mathrm{C}$ in turns, and the holding time was three minutes. The dynamic compressive properties were tested on the split Hopkinson pressure bar (SHPB). The specimens were the shape of a cylinder $(\phi 4 \mathrm{~mm} \times 4 \mathrm{~mm})$, and each alloy was loaded under 0.3 atmospheres, 0.4 atmospheres, and 0.5 atmospheres. In order to ensure the accuracy of the experimental data, two ends of the specimens were rubbed down to make them parallel to each other in the course of the experiments.

\section{Results and Discussion}

\subsection{Crystal Structure and Microstructure Analysis}

The typical X-ray diffraction patterns of these RHEAs are shown in Figure 1. The peaks are consistent with the single phase of the body-centered cubic (BCC) structure without any other phases. In the alloys' solidification process, the phase formation is related to Gibbs free energies of different phases in equilibrium. Because of the high configuration entropy in some RHEAs, the solid solution phase with the lowest energy can stay stable at RT $[18,19]$. Accordingly, the phase can be predicted in the alloys' design process. The atomic-size difference $(\delta)$ and the single-phase formation ability $(\Omega)$ combining the effects of $\Delta \mathrm{S}_{\text {mix }}$ and $\Delta \mathrm{H}_{\text {mix }}$ [20] are calculated and displayed in Table 1; they are in the range of the single-phase formation. 
The metallography of these as-cast RHEAs is shown in Figure 2. Four kinds of RHEAs display dendritic structures, but each composition has a different morphology. In Figure $2 \mathrm{a}$, the primary dendrites intersect with secondary dendrites, and the dendrites are distributed as a network in the high-magnification images. As shown in Figure 2b, the secondary dendrites grow from both sides of the primary dendrites, and some dendrites have a large size in the after-solidified region. The microstructure of the $\mathrm{ZrTiHfNb}_{0.5} \mathrm{Mo}_{0.5}$ alloy displays reticulate dendrites in Figure $2 \mathrm{c}$, which is beneficial to plasticity and strength. Figure $2 \mathrm{~d}$ demonstrates the relatively large dendrite structure of the $\mathrm{ZrTiHfNb}_{0.5} \mathrm{Ta}_{0.5}$ alloy. The dendrites are not connected, and the secondary dendrites are perpendicular to the primary dendrite, leading to the low strength of these alloys.

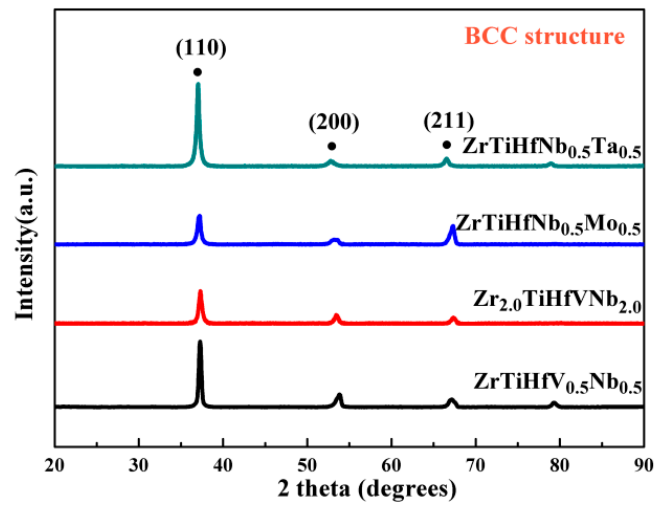

Figure 1. X-ray diffraction patterns of the refractory high-entropy alloys (RHEAs).

Table 1. The relevant thermodynamic parameters and valence electron concentration (VEC) of the refractory alloys.

\begin{tabular}{|c|c|c|c|c|c|}
\hline Alloy & $\Omega$ & Delta/\% & $\mathrm{H}_{\text {mix }}\left(\mathrm{KJ} \cdot \mathrm{mol}^{-1}\right)$ & $S_{\text {mix }}$ & $\mathrm{T}_{\mathrm{m}}(\mathrm{K})$ \\
\hline $\mathrm{ZrTiHfV}_{0.5} \mathrm{Nb}_{0.5}$ & 2.58 & 5.88 & -9.44 & 12.9671 & 2257 \\
\hline $\mathrm{Zr}_{2.0} \mathrm{TiHfVNb}_{2.0}$ & 2.19 & 6.05 & -11.77 & 12.8860 & 2336 \\
\hline $\mathrm{ZrTiHfNb}_{0.5} \mathrm{Mo}_{0.5}$ & 1.62 & 5.10 & -16.70 & 12.9671 & 2349 \\
\hline $\mathrm{ZrTiHfNb}_{0.5} \mathrm{Ta}_{0.5}$ & 2.83 & 4.26 & -9.44 & 12.9671 & 2398 \\
\hline
\end{tabular}

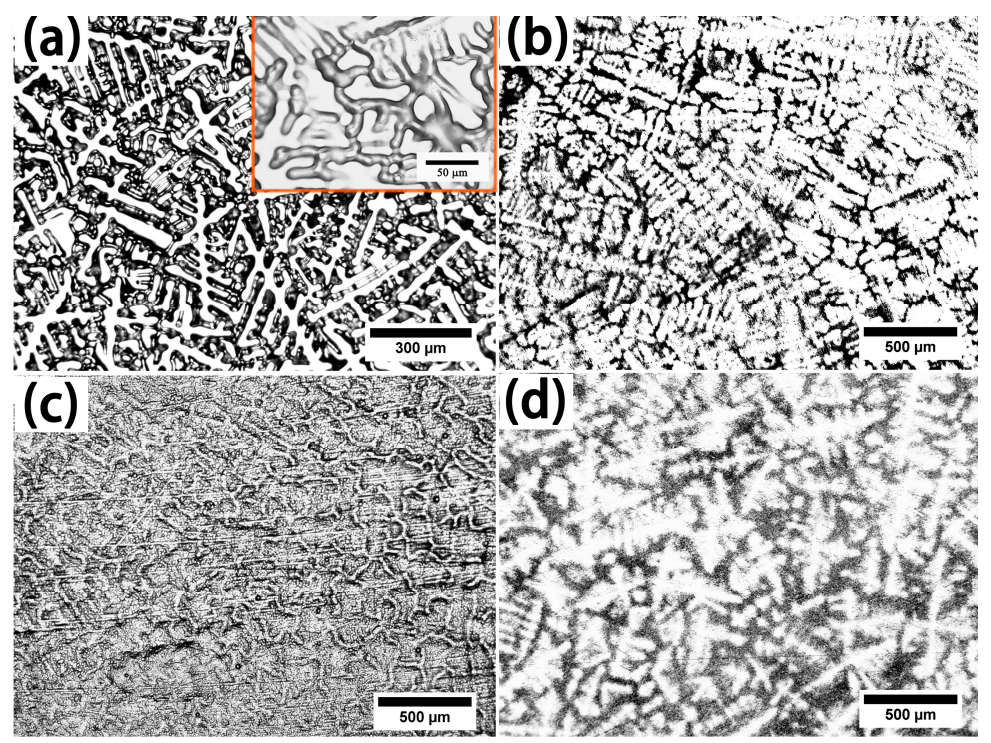

Figure 2. The microstructures of the as-cast RHEAs after being etched: (a) $\mathrm{ZrTiHfV}_{0.5} \mathrm{Nb}_{0.5}$; (b) $\mathrm{Zr}_{2.0} \mathrm{TiHfVNb}_{2.0}$; (c) $\mathrm{ZrTiHfNb}_{0.5} \mathrm{Mo}_{0.5}$; (d) $\mathrm{ZrTiHfNb}_{0.5} \mathrm{Ta}_{0.5}$. 
The components results of these alloys for different regions are displayed in Table 2, and the backscattered electron images are shown in Figure 3. The degree of segregation in the alloys is characterized by the segregation ratio $\left(S_{R}\right)$ :

$$
S_{R}=C_{B}^{i} / C_{A}^{i}
$$

where $C_{A}^{i}$ is the atomic percentage of the $i$ th element in dendrites, and $C_{B}^{i}$ is in the interdendrites. In the $\mathrm{ZrTiHfV}_{0.5} \mathrm{Nb}_{0.5}$ and $\mathrm{Zr}_{2.0} \mathrm{TiHfVNb}_{2.0}$ alloys, the five elements with a similar melting point are distributed evenly in the dendrites and interdendrites. With the addition of Mo and Ta with high melting, there is a clear segregation in the $\mathrm{ZrTiHfNb}_{0.5} \mathrm{Mo}_{0.5}$ and $\mathrm{ZrTiHfNb}{ }_{0.5} \mathrm{Ta}_{0.5}$ alloys. Zr, with a low melting point, is gathered in the interdendrites, and Mo and Ta are concentrated in the dendrites. The melting point of $\mathrm{Ti}$ and Hf is moderate, and these are distributed uniformly in the dendrites and interdendrites.

Table 2. The components analysis of the RHEAs.

\begin{tabular}{ccccccccc}
\hline Alloys & Region & $\mathbf{Z r}$ & $\mathbf{T i}$ & $\mathbf{H f}$ & $\mathbf{V}$ & $\mathbf{N b}$ & $\mathbf{M o}$ & $\mathbf{T a}$ \\
\hline \multirow{2}{*}{$\mathrm{ZrTiHfV}_{0.5} \mathrm{Nb}_{0.5}$} & Dendrite & 24.31 & 24.34 & 25.91 & 12.03 & 13.42 & - & - \\
& Interdendrite & 22.35 & 23.74 & 26.7 & 13.32 & 13.89 & - & - \\
& $S_{R}$ & 0.92 & 0.98 & 1.03 & 1.11 & 1.04 & - & - \\
\hline \multirow{2}{*}{$\mathrm{Zr}_{2.0} \mathrm{TiHfVNb}_{2.0}$} & Dendrite & 27.57 & 13.58 & 14.65 & 13.4 & 30.8 & - & - \\
& Interdendrite & 25.92 & 13.72 & 14.8 & 14.61 & 30.97 & - & - \\
& $S_{R}$ & 0.94 & 1.01 & 1.01 & 1.09 & 1.01 & - & - \\
\hline \multirow{2}{*}{$\mathrm{ZrTiHfNb}_{0.5} \mathrm{Mo}_{0.5}$} & Dendrite & 22.99 & 21.85 & 25.58 & - & 18.99 & 10.59 & - \\
& Interdendrite & 25.95 & 20.37 & 25.6 & - & 20.35 & 7.73 & - \\
& $S_{R}$ & 1.13 & 0.93 & 1 & - & 1.07 & 0.73 & - \\
\hline \multirow{2}{*}{$\mathrm{ZrTiHfNb}_{0.5} \mathrm{Ta}_{0.5}$} & Dendrite & 23.56 & 21.36 & 23.33 & - & 17.5 & - & 10.78 \\
& Interdendrite & 28.53 & 21.47 & 23.69 & - & 16.38 & - & 6.96 \\
& $S_{R}$ & 1.21 & 1.01 & 1.02 & - & 0.94 & - & 0.65 \\
\hline
\end{tabular}

(a)

(b)

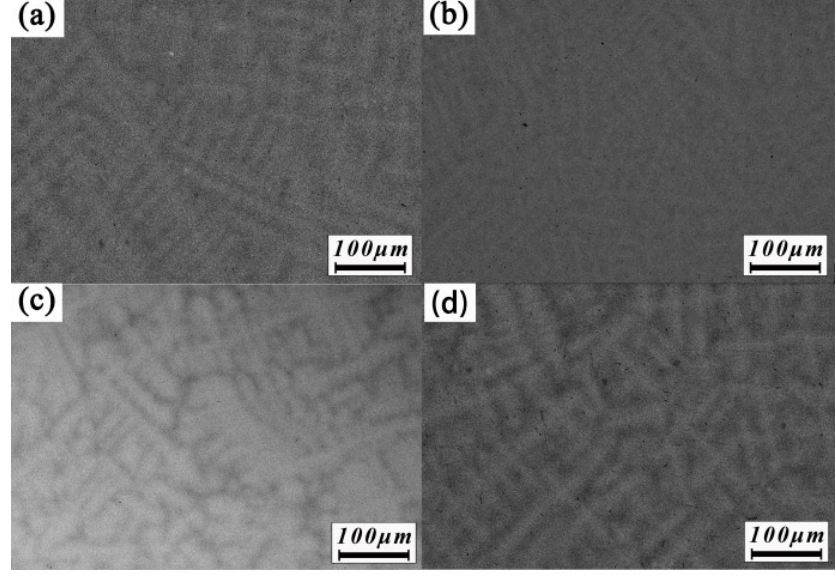

Figure 3. Backscattered electron (BSE) images of the as-cast RHEAs: (a) $\mathrm{ZrTiHfV}_{0.5} \mathrm{Nb}_{0.5}$; (b) $\mathrm{Zr}_{2.0} \mathrm{TiHfVNb}_{2.0}$; (c) $\mathrm{ZrTiHfNb}_{0.5} \mathrm{Mo}_{0.5} ;$ (d) $\mathrm{ZrTiHfNb}_{0.5} \mathrm{Ta}_{0.5}$.

\subsection{Static Compression Properties and Hardness Analysis}

The yield stress of the static compression and hardness are displayed in Figure 4, and the stress-strain curves at RT are shown in Figure 5. These alloys were unfaulted in the processes of experiments (>50\%). The deformation underwent the elastic deformation and plastic deformation stages. A certain degree of hardening occurred as the strain increased. The yield stress of the $\mathrm{ZrTiHfNb}_{0.5} \mathrm{Mo}_{0.5}$ alloy was the highest insofar as the bond energy between Mo and other elements $(\mathrm{Zr}, \mathrm{Ti}, \mathrm{Hf}, \mathrm{V}, \mathrm{and} \mathrm{Nb})$ 
is relatively bigger. In comparison with the ZrTiHfNbMo alloy, whose strain was only 9\% [21], the $\mathrm{ZrTiHfNb}_{0.5} \mathrm{Mo}_{0.5}$ alloy, whose strain is over $50 \%$, is more convenient for machines due to its high plasticity. The yield stress of the $\mathrm{ZrTiHfV}_{0.5} \mathrm{Nb}_{0.5}$ alloy was $995 \mathrm{MPa}$, which is an improvement of nearly $300 \mathrm{MPa}$ when compared with the ZrTiHfVNb alloy [22].

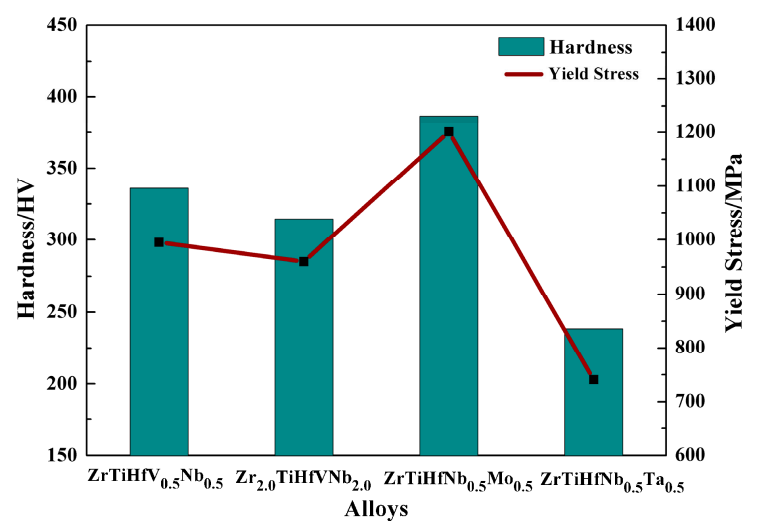

Figure 4. The hardness and compression yield stress of these RHEAs.

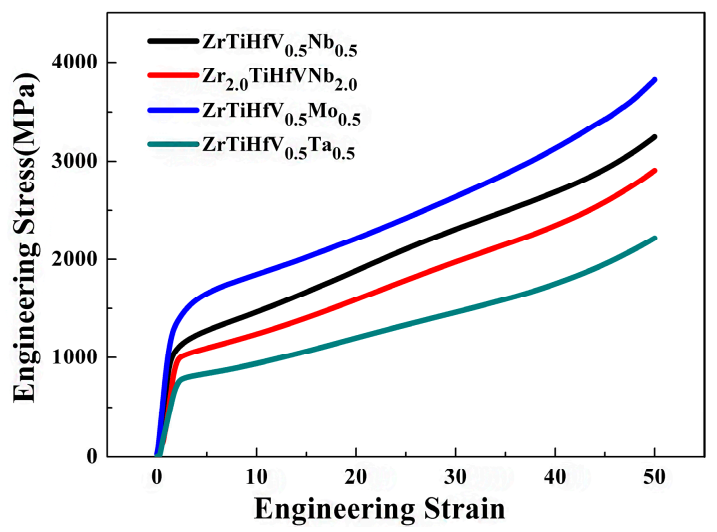

Figure 5. The static compression engineering curves of the RHEAs.

The section images of the $\mathrm{ZrTiHfV}_{0.5} \mathrm{Nb}_{0.5}$ alloy after the compression are shown in Figure 6. The as-cast dendrites display a streamline structure, and the secondary dendrites tend to be paralleled to primary dendrites. Although a small quantity of cracks are observed in Figure $6 b$, many dendrites remain complete comparing Figure $6 a$ with Figure $2 a$, which indicates that the deformability of the $\mathrm{ZrTiHfV}_{0.5} \mathrm{Nb}_{0.5}$ alloy was perfect.

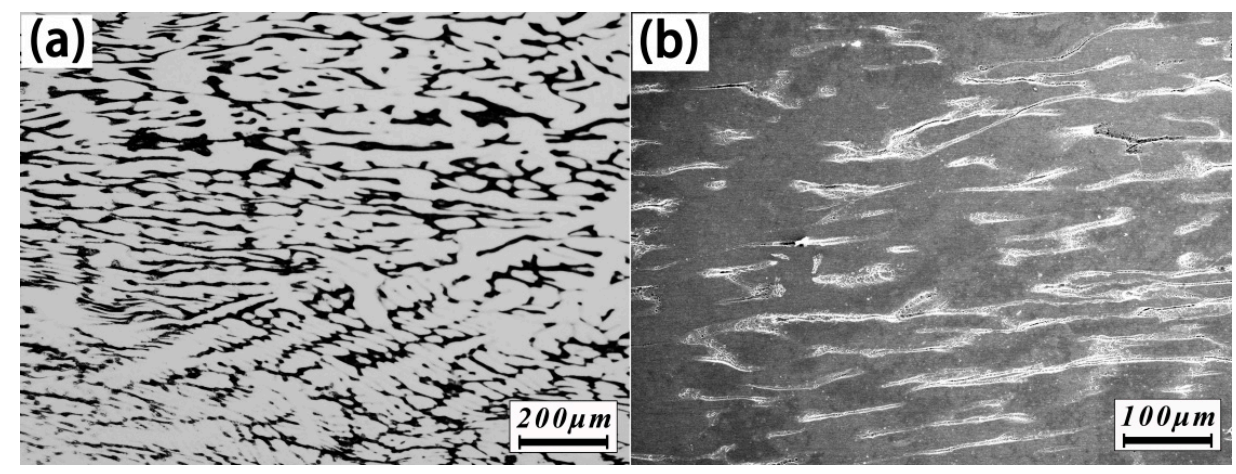

Figure 6. The metallographs of the $\mathrm{ZrTiHfV}_{0.5} \mathrm{Nb}_{0.5}$ alloys after being compressed: (a) Optical microscope $(\mathrm{OM})$; (b) Scanning electron microscope (SEM). 


\subsection{Tensile Properties Analysis}

The stress-strain curves of the tensile experiments are shown in Figure 7. The $\mathrm{ZrTiHfV}_{0.5} \mathrm{Nb}_{0.5}$ and $\mathrm{ZrTiHfNb}_{0.5} \mathrm{Ta}_{0.5}$ alloys underwent a similar process of elastic and plastic deformation, and finally fracture. The tensile stress and elongations of the $\mathrm{ZrTiHfV}_{0.5} \mathrm{Nb}_{0.5}$ and $\mathrm{ZrTiHfNb}_{0.5} \mathrm{Ta}_{0.5}$ alloys were $820 \mathrm{MPa}$ and $4.5 \%$, and $696 \mathrm{MPa}$ and $8 \%$, respectively. The $\mathrm{Zr}_{2.0} \mathrm{TiHfVNb}_{2.0}$ and $\mathrm{ZrTiHfNb}_{0.5} \mathrm{Mo}_{0.5}$ alloys failed in the elastic region by a stress level of $349 \mathrm{MPa}$ and $530 \mathrm{MPa}$, respectively. The VEC of the RHEAs is calculated as:

$$
\mathrm{VEC}=\sum C_{i} * \mathrm{VEC}_{i}
$$

where $C_{i}$ is the atomic percentage of the $i$ th element and $V E C_{i}$ is its valence electron. Figure 8 shows the relationship between the VEC and the tensile strain of the researched RHEAs. It shows that the VEC and tensile strain have an opposite trend, which reveals that the RHEAs with good plasticity can be obtained by controlling the VEC.

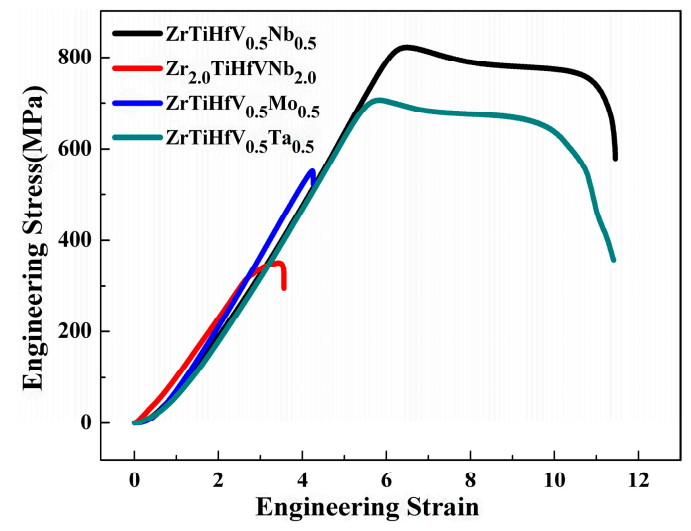

Figure 7. The tension stress-strain curves of the RHEAs.

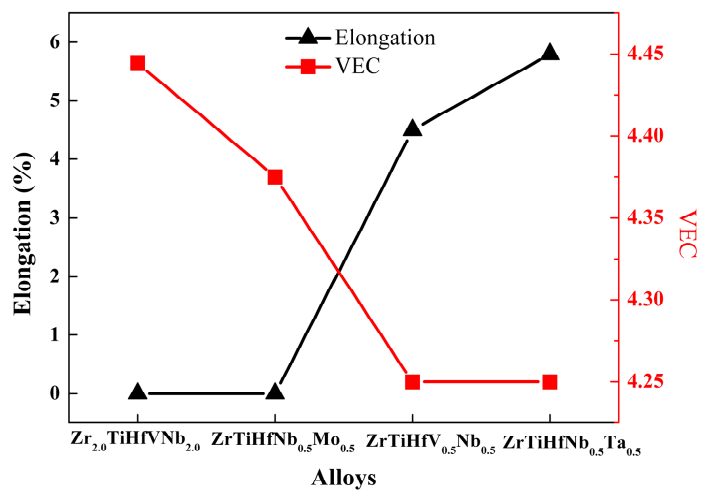

Figure 8. The relationship between the valence electron concentration (VEC) and tensile elongation of different RHEAs.

\subsection{High-Temperature Compressive Properties}

The compressive curves of the $\mathrm{ZrTiHfV}_{0.5} \mathrm{Nb}_{0.5}, \mathrm{Zr}_{2.0} \mathrm{TiHfVNb}_{2.0}, \mathrm{ZrTiHfNb}_{0.5} \mathrm{Mo}_{0.5}$, and $\mathrm{ZrTiHfNb}_{0.5} \mathrm{Ta}_{0.5}$ alloys tested at high temperature $\left(700^{\circ} \mathrm{C}, 800^{\circ} \mathrm{C}\right.$, and $\left.900{ }^{\circ} \mathrm{C}\right)$ are shown in Figure 9 . The stress increased rapidly and then decreased to a stable value with an increase in deformation. The stress of the alloys was closely related to the temperature. As a high temperature could provide much more energy, it would promote a movement of dislocation, vacancy, and grain boundary, which could in turn decrease the stress. The high-temperature yield stress of the $\mathrm{ZrTiHfV}_{0.5} \mathrm{Nb}_{0.5}$ alloy was $337 \mathrm{MPa}$ at $700{ }^{\circ} \mathrm{C}, 116 \mathrm{MPa}$ at $800{ }^{\circ} \mathrm{C}$, and $46 \mathrm{MPa}$ at $900^{\circ} \mathrm{C}$. When adjusting the content of $\mathrm{Nb}$, the 
yield stress of the $\mathrm{Zr}_{2.0} \mathrm{TiHfVNb}_{2.0}$ alloy was $647 \mathrm{MPa}$ at $700{ }^{\circ} \mathrm{C}, 476 \mathrm{MPa}$ at $800{ }^{\circ} \mathrm{C}$, and $165 \mathrm{MPa}$ at $900{ }^{\circ} \mathrm{C}$. Because Mo has good ability of softening resistance at high temperature, the yield stress of the $\mathrm{ZrTiHfNb}_{0.5} \mathrm{Mo}_{0.5}$ alloy remained at $937 \mathrm{MPa}$ at $700{ }^{\circ} \mathrm{C}, 539 \mathrm{MPa}$ at $800{ }^{\circ} \mathrm{C}$, and $274 \mathrm{MPa}$ at $900{ }^{\circ} \mathrm{C}$. It is therefore a promising candidate in the high-temperature alloy category. Although Ta has the highest melting point, the yield stress of the $\mathrm{ZrTiHfNb}_{0.5} \mathrm{Ta}_{0.5}$ alloy was $383 \mathrm{MPa}$ at $700{ }^{\circ} \mathrm{C}, 170 \mathrm{MPa}$ at $800{ }^{\circ} \mathrm{C}$, and $112 \mathrm{MPa}$ at $900{ }^{\circ} \mathrm{C}$ due to the low strength of Ta.
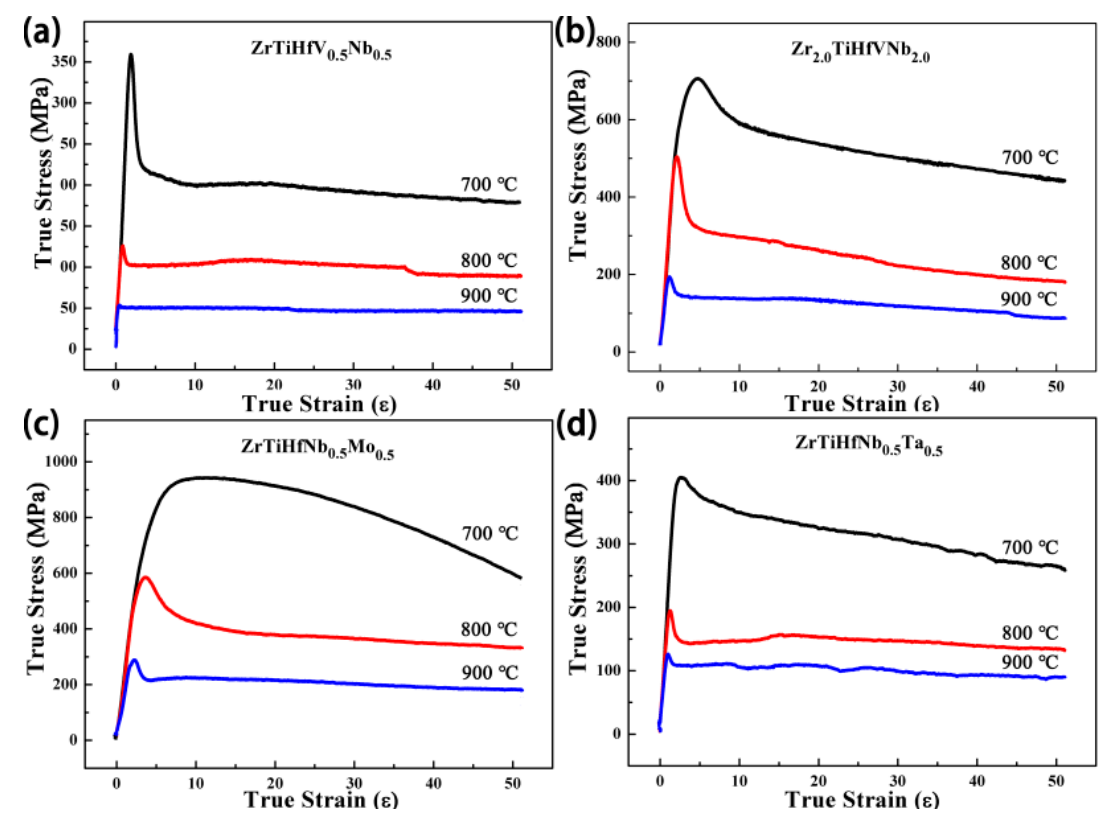

Figure 9. The high-temperature compression stress-strain curves of the alloys: (a) $\mathrm{ZrTiHfV}_{0.5} \mathrm{Nb}_{0.5}$; (b) $\mathrm{Zr}_{2.0} \mathrm{TiHfVNb}_{2.0}$; (c) $\mathrm{ZrTiHfNb}_{0.5} \mathrm{Mo}_{0.5}$; (d) $\mathrm{ZrTiHfNb}_{0.5} \mathrm{Ta}_{0.5}$.

In Figure $10 \mathrm{a}$, no other phase was produced during the heating process $\left(800{ }^{\circ} \mathrm{C}\right)$ in the $\mathrm{ZrTiHfNb}_{0.5} \mathrm{Ta}_{0.5}$ alloy. Figure $10 \mathrm{~b}$ shows the post-compression metallograph. The original grain was compressed, and a small amount of equiaxial grains gathered along the direction of the deformation, which is a typical fracture after a high-temperature compression.

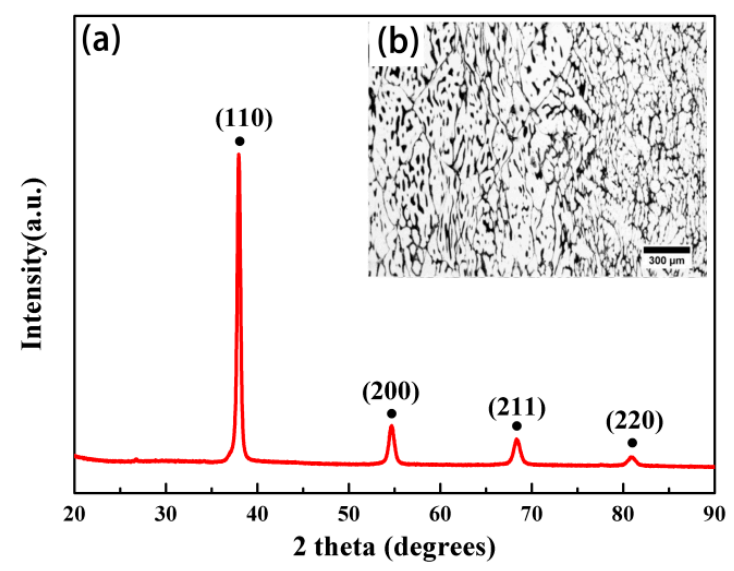

Figure 10. The microstructures of the $\mathrm{ZrTiHfNb}_{0.5} \mathrm{Ta}_{0.5}$ alloys after being compressed at $800{ }^{\circ} \mathrm{C}$ : (a) XRD pattern; (b) metallography.

The density and compressive properties of the prepared RHEAs and other RHEAs from previous research are shown in Table 3. The strength matches well with plasticity by controlling the VEC. 
With regard to high-temperature stress, the special strength of the $\mathrm{ZrTiHfNb}_{0.5} \mathrm{Mo}_{0.5}$ alloy at $800{ }^{\circ} \mathrm{C}$ was relatively higher, and the application has apparent preponderance in the elevated field.

Table 3. The density and mechanical properties at room temperature (RT) and high temperature compared with referenced literature.

\begin{tabular}{|c|c|c|c|c|c|c|c|}
\hline Alloys & $\begin{array}{l}\text { Density/ } \\
\mathrm{g} \cdot \mathrm{cm}^{-3}\end{array}$ & Strain/\% & $\begin{array}{c}\text { Yield } \\
\text { Stress/ } \\
\text { MPa }\end{array}$ & $\begin{array}{c}\text { Specific } \\
\text { Strength/ } \\
\mathrm{MPa} \cdot \mathrm{cm}^{3} / \mathrm{g}\end{array}$ & $\begin{array}{c}\text { Elevated } \\
\text { Temperature } \\
\text { Strength } \\
\left(800^{\circ} \mathrm{C}\right)\end{array}$ & $\begin{array}{c}\text { Specific } \\
\text { Strength/ } \\
\mathrm{MPa} \cdot \mathrm{cm}^{3} / \mathrm{g} \\
\left(800^{\circ} \mathrm{C}\right)\end{array}$ & VEC \\
\hline CrNbTiZr & 6.70 & $6 \%$ & 1260 & 188.06 & 300 & $44.78[23]$ & 4.75 \\
\hline HfMoNbTiZr & 8.69 & $9 \%$ & 1575 & 181.24 & 635 & $73.07[21]$ & 4.60 \\
\hline HfNbTiVZr & 8.06 & $30 \%$ & 1170 & 145.16 & 408 & $50.62[22]$ & 4.40 \\
\hline HfNbTaTiZr & 9.94 & $>50 \%$ & 929 & 93.46 & 535 & 53.82 [9] & 4.40 \\
\hline $\mathrm{ZrTiHfV}_{0.5} \mathrm{Nb}_{0.5}$ & 8.08 & $>50 \%$ & 990 & 122.51 & 125 & 15.47 & 4.25 \\
\hline $\mathrm{Zr}_{2.0} \mathrm{TiHfVNb}_{2.0}$ & 7.83 & $>50 \%$ & 956 & 122.17 & 507 & 64.79 & 4.43 \\
\hline $\mathrm{ZrTiHfNb}_{0.5} \mathrm{Mo}_{0.5}$ & 8.43 & $>50 \%$ & 1195 & 141.77 & 595 & 70.59 & 4.38 \\
\hline $\mathrm{ZrTiHfNb}_{0.5} \mathrm{Ta}_{0.5}$ & 9.14 & $>50 \%$ & 738 & 80.79 & 193 & 21.13 & 4.25 \\
\hline
\end{tabular}

\subsection{Dynamic Compressive Properties Analysis}

The dynamic compressive curves of RHEAs are exhibited in Figure 11. Each alloy is loaded by 0.3 atmospheres, 0.4 atmospheres, and 0.5 atmospheres. At the same pressure, the strain rate of these alloys is obviously different, but the yield stress of these alloys has no obvious change with the strain rate increase. The stress displays a rapid uptrend because the strain hardening and strain rate strengthening are dominant in the plastic stage. With the rapid deformation increase, the heat could not dissipate, which would have led to the materials' thermal softening. In this condition, the stress of the alloys is the result of both heat softening and the reinforcement produced by strain. In the $\mathrm{ZrTiHfV}_{0.5} \mathrm{Nb}_{0.5}$ and $\mathrm{ZrTiHfNb}_{0.5} \mathrm{Mo}_{0.5}$ alloys, the stress decreases slightly with the strain increase because the heat softening effect is preponderant. However, the strengthening and softening effects remain balanced in the $\mathrm{Zr}_{2.0} \mathrm{TiHfVNb}_{2.0}$ and $\mathrm{ZrTiHfNb}_{0.5} \mathrm{Ta}_{0.5}$ alloys, leading the stress to remain the same.

(a)

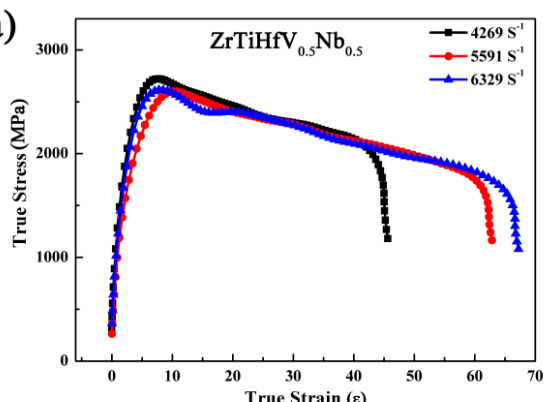

(c)

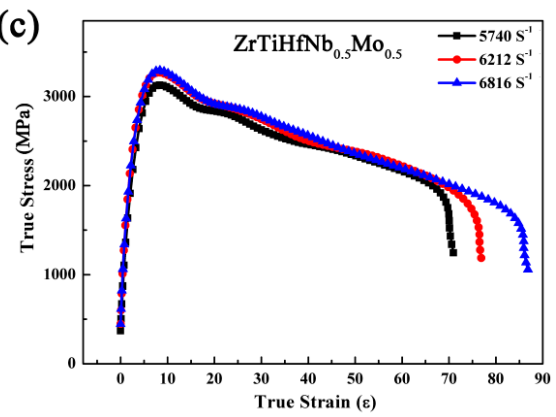

(b)

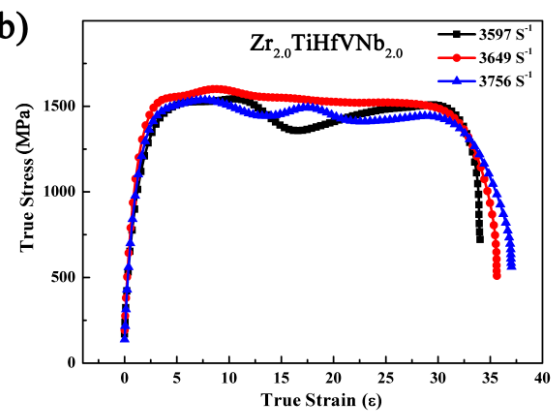

(d)

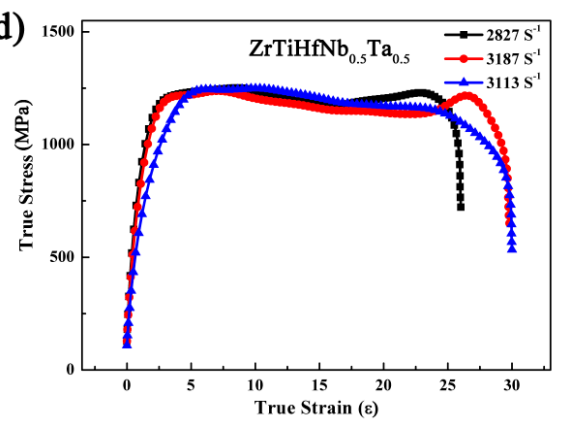

Figure 11. The dynamic compression stress-strain curves of the RHEAs: (a) $\mathrm{ZrTiHfV}_{0.5} \mathrm{Nb}_{0.5}$; (b) $\mathrm{Zr}_{2.0} \mathrm{TiHfVNb}_{2.0}$; (c) $\mathrm{ZrTiHfNb}_{0.5} \mathrm{Mo}_{0.5}$; (d) $\mathrm{ZrTiHfNb}_{0.5} \mathrm{Ta}_{0.5}$. 
In Table 4, the yield stress is higher than the static condition, but the energy absorption of the four RHEAs is apparently different. In the dynamic deformation process, these alloys with coordination between strength and plasticity undergo a large deformation and energy absorption. The average stress of the $\mathrm{ZrTiHfNb}_{0.5} \mathrm{Mo}_{0.5}$ alloy is $3337 \mathrm{MPa}$, and the energy absorption is $8.46 \mathrm{MJ} \cdot \mathrm{m}^{-2}$, thereby providing a promising material under dynamic conditions. Although the plasticity of the $\mathrm{ZrTiHfNb}_{0.5} \mathrm{Ta}_{0.5}$ alloy is high in the static condition, the strain is only $24.86 \%$ in the dynamic deformation process due to its low strength.

Table 4. The dynamic compressive mechanical properties and energy absorption of the RHEAs.

\begin{tabular}{|c|c|c|c|c|c|}
\hline \multirow{2}{*}{ Alloys } & \multirow{2}{*}{$\begin{array}{c}\text { Average } \\
\text { Stress/MPa }\end{array}$} & \multirow{2}{*}{$\begin{array}{l}\text { Average } \\
\text { Strain/\% }\end{array}$} & \multicolumn{3}{|c|}{ Energy Absorption/(MJ.m $\left.{ }^{-2}\right)$} \\
\hline & & & $0.3 \mathrm{Atm}$ & $0.4 \mathrm{Atm}$ & $0.5 \mathrm{Atm}$ \\
\hline $\mathrm{ZrTiHfV}_{0.5} \mathrm{Nb}_{0.5}$ & 2642 & 50.03 & 4.21 & 4.08 & 5.71 \\
\hline $\mathrm{Zr}_{2.0} \mathrm{TiHfVNb}_{2.0}$ & 1594 & 31.98 & 1.93 & 2.09 & 2.04 \\
\hline $\mathrm{ZrTiHfNb}_{0.5} \mathrm{Mo}_{0.5}$ & 3337 & 70.1 & 7.02 & 7.78 & 8.46 \\
\hline $\mathrm{ZrTiHfNb}_{0.5} \mathrm{Ta}_{0.5}$ & 1237 & 24.86 & 1.22 & 1.36 & 1.34 \\
\hline
\end{tabular}

The fracture surface is shown in Figure 12. The fracture morphology of the $\mathrm{ZrTiHfV}_{0.5} \mathrm{Nb}_{0.5}$ alloy had some shallow tough fossae, and part of the section was comparatively smooth (Figure 12a), which indicates that the fracture model of the alloys was a tough-brittle fracture. With the $\mathrm{Zr}$ and $\mathrm{Nb}$ increase, the fracture surface of the $\mathrm{Zr}_{2.0} \mathrm{TiHfVNb}_{2.0}$ alloy exhibited river-like features (Figure 12b). When adding Mo in alloys, the fracture appearance uniformly distributed the tough fossae (Figure 12c). The fracture surface of $\mathrm{ZrTiHfNb}_{0.5} \mathrm{Ta}_{0.5}$ alloy was smooth (Figure 12d), which shows that its plasticity was poor under dynamic conditions.

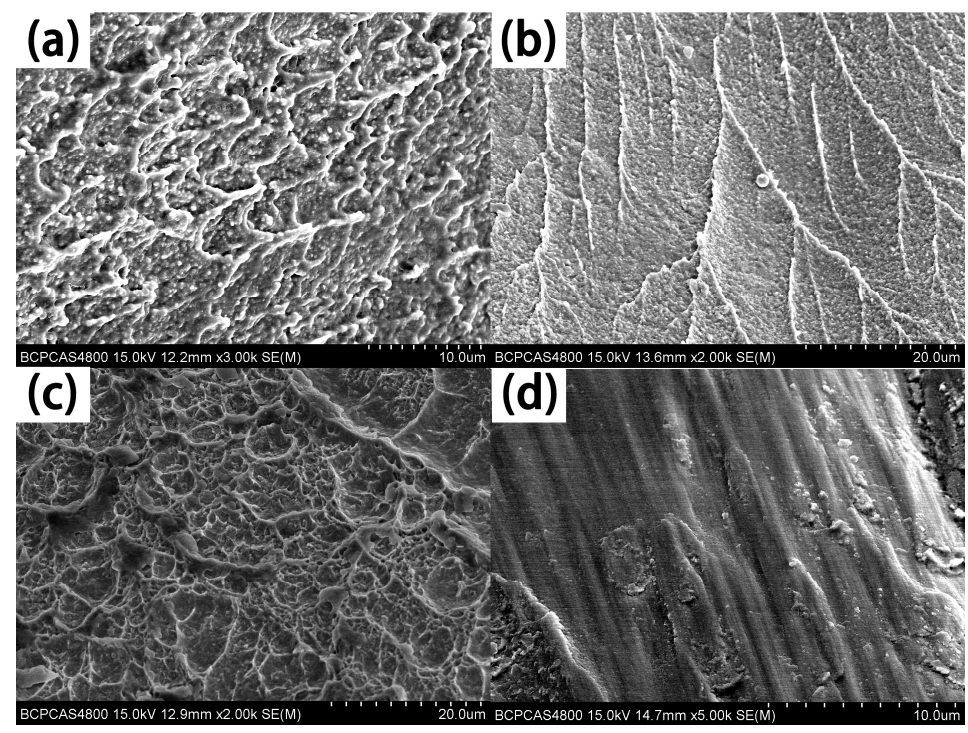

Figure 12. Scanning electron microscopy (SEM) images of these RHEAs after being dynamically compressed and etched: (a) $\mathrm{ZrTiHfV}_{0.5} \mathrm{Nb}_{0.5}$; (b) $\mathrm{Zr}_{2.0} \mathrm{TiHfVNb}_{2.0}$; (c) $\mathrm{ZrTiHfNb}_{0.5} \mathrm{Mo}_{0.5}$; (d) $\mathrm{ZrTiHfNb}_{0.5} \mathrm{Ta}_{0.5}$.

\section{Conclusions}

In this paper, four kinds of RHEAs with high plasticity $\left(\mathrm{ZrTiHfV}_{0.5} \mathrm{Nb}_{0.5}, \mathrm{Zr}_{2.0} \mathrm{TiHfVNb}_{2.0}\right.$, $\mathrm{ZrTiHfNb}_{0.5} \mathrm{Mo}_{0.5}$, and $\mathrm{ZrTiHfNb}_{0.5} \mathrm{Ta}_{0.5}$ ) were designed by controlling the $\mathrm{VEC}$, and they were synthesized via vacuum arc melting in order to certify the accuracy of the VEC principle. Based on the results we obtained and the subsequent analysis, we drew the following conclusions: 
(1) The crystal structure of the RHEAs was identified as a BCC structure and the dendrites were found in the optical microscope.

(2) The compressive strain of these alloys was higher than $50 \%$ and the compressive strength was relatively higher. The RHEAs with the minimum VEC exhibited the maximum tensile deformation.

(3) The addition of $\mathrm{Nb}, \mathrm{Mo}$, and Ta contributed to a high-temperature strength.

(4) It would be beneficial to explore new-type RHEAs with good plasticity by controlling the VEC. RHEAs that combine good plasticity and high strength would be convenient for processing and manufacturing.

Author Contributions: Yunkai Li and Yiwen Chen conceived and designed the experiments; Yiwen Chen, Chao Wu and Ziqi Xu performed the experiments; Yiwen Chen and Bo Cheng analyzed the data; Xingwang Cheng and Yunkai Li contributed materials and analysis tools; Yiwen Chen wrote the paper.

Conflicts of Interest: The authors declare no conflict of interest.

\section{References}

1. Cantor, B.; Chang, I.T.H.; Knight, P.; Vincent, A.J.B. Microstructural development in equiatomic multicomponent alloys. Mater. Sci. Eng. A 2004, 375, 213-218. [CrossRef]

2. Yeh, J.W.; Chen, S.K.; Lin, S.J.; Gan, J.Y.; Chin, T.S.; Shun, T.T.; Tsau, C.H.; Chang, S.Y. Nanostructured high-entropy alloys with multiple principal elements: Novel alloy design concepts and outcomes. Adv. Eng. Mater. 2004, 6, 299-303. [CrossRef]

3. Yeh, J.-W.; Chang, S.-Y.; Hong, Y.-D.; Chen, S.-K.; Lin, S.-J. Anomalous decrease in X-ray diffraction intensities of $\mathrm{Cu}-\mathrm{Ni}-\mathrm{Al}-\mathrm{Co}-\mathrm{Cr}-\mathrm{Fe}-\mathrm{Si}$ alloy systems with multi-principal elements. Mater. Chem. Phys. 2007, 103, 41-46. [CrossRef]

4. Xiao, D.H.; Zhou, P.F.; Wu, W.Q.; Diao, H.Y.; Gao, M.C.; Song, M.; Liaw, P.K. Microstructure, mechanical and corrosion behaviors of AlCoCuFeNi-(Cr,Ti) high entropy alloys. Mater. Des. 2017, 116, 438-447. [CrossRef]

5. Daoud, H.M.; Manzoni, A.M.; Volkl, R.; Wanderka, N.; Glatzel, U. Oxidation Behavior of Al8Co17Cr17Cu8Fe17Ni33, Al23Co15Cr23Cu8Fe15Ni15, and Al17Co17Cr17Cu17Fe17Ni17 Compositionally Complex Alloys (High-Entropy Alloys) at Elevated Temperatures in Air. Adv. Eng. Mater. 2015, 17, 1134-1141. [CrossRef]

6. Gorr, B.; Azim, M.; Christ, H.J.; Mueller, T.; Schliephake, D.; Heilmaier, M. Phase equilibria, microstructure, and high temperature oxidation resistance of novel refractory high-entropy alloys. J. Alloys Compd. 2015, 624, 270-278. [CrossRef]

7. Melnick, A.B.; Soolshenko, V.K. Thermodynamic design of high-entropy refractory alloys. J. Alloys Compd. 2017, 694, 223-227. [CrossRef]

8. Senkov, O.N.; Wilks, G.B.; Scott, J.M.; Miracle, D.B. Mechanical properties of Nb25Mo25Ta25W25 and V20Nb20Mo20Ta20W20 refractory high entropy alloys. Intermetallics 2011, 19, 698-706. [CrossRef]

9. Senkov, O.N.; Scott, J.M.; Senkova, S.V.; Meisenkothen, F.; Miracle, D.B.; Woodward, C.F. Microstructure and elevated temperature properties of a refractory TaNbHfZrTi alloy. J. Mater. Sci. 2012, 47, 4062-4074. [CrossRef]

10. Senkov, O.N.; Scott, J.M.; Senkova, S.V.; Miracle, D.B.; Woodward, C.F. Microstructure and room temperature properties of a high-entropy TaNbHfZrTi alloy. J. Alloys Compd. 2011, 509, 6043-6048. [CrossRef]

11. Juan, C.C.; Tseng, K.K.; Hsu, W.L.; Tsai, M.H.; Tsai, C.W.; Lin, C.M.; Chen, S.K.; Lin, S.J.; Yeh, J.W. Solution strengthening of ductile refractory HfMoxNbTaTiZr high-entropy alloys. Mater. Lett. 2016, 175, $284-287$. [CrossRef]

12. Yurchenko, N.Y.; Stepanov, N.D.; Zherebtsov, S.V.; Tikhonovsky, M.A.; Salishchev, G.A. Structure and mechanical properties of B2 ordered refractory AlNbTiVZr x $(x=0-1.5)$ high-entropy alloys. Mater. Sci. Eng. A 2017, 704, 82-90. [CrossRef]

13. Senkov, O.N.; Semiatin, S.L. Microstructure and properties of a refractory high-entropy alloy after cold working. J. Alloys Compd. 2015, 649, 1110-1123. [CrossRef]

14. Tsai, M.H.; Fan, A.C.; Wang, H.A. Effect of atomic size difference on the type of major intermetallic phase in arc-melted CoCrFeNiX high-entropy alloys. J. Alloys Compd. 2017, 695, 1479-1487. [CrossRef] 
15. Nagasako, N.; Jahnátek, M.; Asahi, R.; Hafner, J. Anomalies in the response of V, Nb, and Ta to tensile and shear loading: Ab initiodensity functional theory calculations. Phys. Rev. B 2010, 81, 094108. [CrossRef]

16. Qi, L.; Chrzan, D.C. Tuning ideal tensile strengths and intrinsic ductility of bcc refractory alloys. Phys. Rev. Lett. 2014, 112, 115503. [CrossRef] [PubMed]

17. Sheikh, S.; Shafeie, S.; Hu, Q.; Ahlstrom, J.; Persson, C.; Vesely, J.; Zyka, J.; Klement, U.; Guo, S. Alloy design for intrinsically ductile refractory high-entropy alloys. J. Appl. Phys. 2016, 120, 164902. [CrossRef]

18. King, D.J.M.; Middleburgh, S.C.; McGregor, A.G.; Cortie, M.B. Predicting the formation and stability of single phase high-entropy alloys. Acta Mater. 2016, 104, 172-179. [CrossRef]

19. Miracle, D.B.; Senkov, O.N. A critical review of high entropy alloys and related concepts. Acta Mater. 2017, 122, 448-511. [CrossRef]

20. Zhang, Y.; Yang, X.; Liaw, P.K. Alloy Design and Properties Optimization of High-Entropy Alloys. JOM 2012, 64, 830-838. [CrossRef]

21. Guo, N.N.; Wang, L.; Luo, L.S.; Li, X.Z.; Su, Y.Q.; Guo, J.J.; Fu, H.Z. Microstructure and mechanical properties of refractory MoNbHfZrTi high-entropy alloy. Mater. Des. 2015, 81, 87-94. [CrossRef]

22. Fazakas, E.; Zadorozhnyy, V.; Varga, L.K.; Inoue, A.; Louzguine-Luzgin, D.V.; Tian, F.Y.; Vitos, L. Experimental and theoretical study of Ti20Zr20Hf20Nb20X20 (X = V or Cr) refractory high-entropy alloys. Int. J. Refract Met. Hard Mater. 2014, 47, 131-138. [CrossRef]

23. Senkov, O.N.; Senkova, S.V.; Miracle, D.B.; Woodward, C. Mechanical properties of low-density, refractory multi-principal element alloys of the Cr-Nb-Ti-V-Zr system. Mater. Sci. Eng. A 2013, 565, 51-62. [CrossRef]

(C) 2018 by the authors. Licensee MDPI, Basel, Switzerland. This article is an open access article distributed under the terms and conditions of the Creative Commons Attribution (CC BY) license (http:/ / creativecommons.org/licenses/by/4.0/). 